\title{
Profiling non-lysyl tRNAs in HIV-1
}

\author{
MARIANA PAVON-ETERNOD, ${ }^{1,5}$ MIN WEI, ${ }^{2,3,5}$ TAO PAN, $^{1}$ and LAWRENCE KLEIMAN ${ }^{2,3,4}$ \\ ${ }^{1}$ Department of Biochemistry and Molecular Biology, University of Chicago, Chicago, Illinois 60637, USA \\ ${ }^{2}$ Lady Davis Institute for Medical Research and McGill AIDS Centre, Jewish General Hospital, Montreal, Quebec H3T1E2, Canada \\ ${ }^{3}$ Department of Medicine, McGill University, Montreal, Quebec H3T1E2, Canada \\ ${ }^{4}$ Department of Microbiology and Immunology, McGill University, Montreal, Quebec H3T1E2, Canada
}

\begin{abstract}
During its assembly, human HIV-1 selectively packages the tRNA ${ }^{\text {Lys }}$ isoacceptors, including tRNA ${ }^{\text {Lys3 }}$, the primer for the reverse transcriptase. However, other low molecular weight RNA species are also seen in the virus. We profiled the tRNAs packaged into HIV-1 using microarray analysis and validated our results by two-dimensional gel electrophoresis and RT-PCR. In addition to TRNA $^{\text {Lys }}$ isoacceptors, TRNA $^{\text {Asn }}$ and the rare isoacceptor of tRNA ${ }^{\text {lle }}$ are also selectively packaged. In Gag viral-like particles missing the GagPol protein, overall tRNA incorporation is reduced by $>\mathbf{8 0} \%$. This reduction is significantly greater than can be accounted for by the reduction in tRNA ${ }^{\text {Lys }}$ isoacceptors, $T R N A^{A s n}$ and TRNA $^{\text {lle }}$, suggesting that incorporation of other tRNAs may also require the GagPol protein. These results demonstrate selective incorporation of non-lysyl tRNAs into HIV-1 and highlight the application of microarrays as a novel method to study tRNA incorporation into viruses.
\end{abstract}

Keywords: HIV; microarray; tRNA; viral packaging

\section{INTRODUCTION}

During HIV-1 assembly, the tRNA ${ }^{\text {Lys }}$ isoacceptors, $\mathrm{tRNA}^{\text {Lys } 1,2}$ and $\mathrm{tRNA}^{\mathrm{Lys} 3}$, are selectively incorporated into the virus (Jiang et al. 1993). tRNA ${ }^{\text {Lys3 }}$ anneals to the primer binding site (PBS) in the $5^{\prime}$ regions of the viral RNA genome, and serves as the primer for initiating reverse transcription of minus strand strong stop DNA. tRNA $^{\text {Lys } 1,2}$, which differs from tRNA ${ }^{\text {Lys3 }}$ by 14 or 16 bases, is the isoacceptor of tRNA $^{\text {Lys3 }}$ and differs by 1 base pair (bp) in the anticodon stem (Raba et al. 1979). While tRNA ${ }^{\text {Lys1,2 }}$ does not function as a primer in HIV-1, it may play a role in the import of the pre-integration complex into the nucleus of the infected cell (Zaitseva et al. 2006).

Previous work has indicated that the nucleoprotein complex involved in promoting the selective incorporation of tRNA ${ }^{\text {Lys }}$ includes the viral precursor proteins Gag and GagPol, viral genomic RNA, lysyl-tRNA synthetase (LysRS), and $\mathrm{tRNA}^{\mathrm{Lys}}$. The formation of this complex involves a specific interaction of Gag with both LysRS (Javanbakht

\footnotetext{
${ }^{5}$ These authors contributed equally to this work.

Reprint requests to: Tao Pan, Department of Biochemistry and Molecular Biology, University of Chicago, Chicago, IL 60637, USA; e-mail: taopan@uchicago.edu; fax: (773) 702-0439; or Lawrence Kleiman, Lady Davis Institute for Medical Research and McGill AIDS Centre, Jewish General Hospital, Montreal, Quebec H3T1E2, Canada; e-mail: lawrence. kleiman@mcgill.ca; fax: (514) 340-8260.

Article published online ahead of print. Article and publication date are at http://www.rnajournal.org/cgi/doi/10.1261/rna.1928110.
}

et al. 2003) and GagPol. tRNA ${ }^{\text {Lys }}$ is bound to LysRS and interacts with the reverse transcriptase segment within GagPol, thus stabilizing the complex (Khorchid et al. 2000). Thus, viral-like particles (VLPs) composed only of Gag have been reported to package only LysRS, and not tRNA $^{\text {Lys }}$ (Cen et al. 2001).

While resolution of HIV-1 low molecular weight RNA by two-dimensional (2D) PAGE shows the tRNA ${ }^{\text {Lys }}$ isoacceptors to be major components of this population, other low molecular weight species can also be seen. In this work, we have identified some of the other tRNAs present in HIV-1 through hybridization of labeled viral RNA to human tRNA microarrays. The microarray contains 40 DNA probes representing all $>270$ human nuclear-encoded tRNA genes as closely related families (Dittmar et al. 2006; PavonEternod et al. 2009). We validated our microarray results by $2 \mathrm{D}$ polyacrylamide gel electrophoresis (2D PAGE) and $\mathrm{RT} / \mathrm{PCR}$. We found that in addition to the tRNA ${ }^{\text {Lys }}$ isoacceptors, tRNA ${ }^{\text {Asn }}$ and the rare isoacceptor of tRNA ${ }^{\text {Ile }}$ are also selectively packaged into HIV-1. Like tRNA ${ }^{\text {Lys }}$, the selective packaging of non-lysyl tRNAs also depends on the GagPol protein of HIV.

\section{RESULTS AND DISCUSSION}

\section{Microarray analysis of viral tRNAs}

Viruses were produced from $293 \mathrm{~T}$ cells transfected with $\mathrm{BH} 10$, a plasmid coding for the BH10 strain of HIV-1. Gag 
viral-like particles (VLPs) were produced from $293 \mathrm{~T}$ cells transfected with GagFS(-), a plasmid coding for all HIV-1 proteins except GagPol (the frameshift in viral RNA responsible for GagPol production has been eliminated in this plasmid). To determine the identity and abundance of tRNAs packaged into HIV-1 and GagVLPs, we applied a previously described microarray method, as applied in studies of tissue-specific expression of human tRNAs (Dittmar et al. 2006) and tRNA expression in cancer tissues and cell lines (Pavon-Eternod et al. 2009; Zhou et al. 2009).

Arrays used for this study contain 40 probes for human nuclear-encoded tRNAs, which represent all $>270$ different human tRNA sequences as closely related families, and 22 probes for all 22 human mitochondrial-encoded tRNAs. The array also includes 42 probes for bacterial tRNAs and 275 probes complementary to short regions in yeast and human rRNA, which serve as hybridization and specificity controls. Each probe is repeated 21 times in the array. After isolation of total RNA from 293T cells, HIV-1, and Gag VLPs, tRNAs in the sample were labeled by selective ligation to a fluorophore-containing oligonucleotide. The labeled samples were hybridized directly onto the array (Fig. 1A). The 293T cellular RNA sample was included as a reference in all array hybridizations to correct for variations in fluorescence labeling and array manufacturing. Since tRNA constitutes up to $30 \%$ of the total RNA, the method requires no amplification and only $1-2 \mu \mathrm{g}$ of total RNA were used per array. The specificity of the array is illustrated by the fluorescence signals derived from human tRNA probes compared to the nonhuman tRNA probes (Fig. 1B,C). As expected, tRNA ${ }^{\text {Lys1,2(CUU) }}$ and tRNA ${ }^{\text {Lys3(UUU) }}$ are present in large quantities in the wild-type HIV sample (Fig. 1D).

As is typically done in two-color microarray analysis, we first analyzed the relative abundance for the nuclear- and mitochondrial-encoded tRNAs in HIV-1 and GagVLPs compared to the total RNA in HEK293T (Fig. 2). Each bar indicates the ratio of viral:cellular RNA hybridization signals for a specific tRNA, such that a ratio of 1 would indicate similar abundance in both samples. A single ratio value is not by itself reflective of selective packaging since the nature of the cellular and viral RNA samples are different. For HEK293T, the total RNA is primarily rRNA and tRNA, whereas for HIV-1 and GagVLP, the total RNA is primarily the HIV genomic RNA and tRNA. However, a comparative analysis across different tRNA species indicates which tRNAs
A

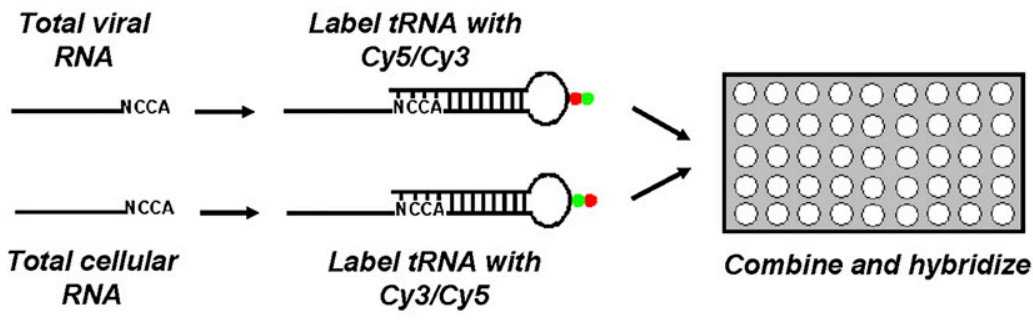

C

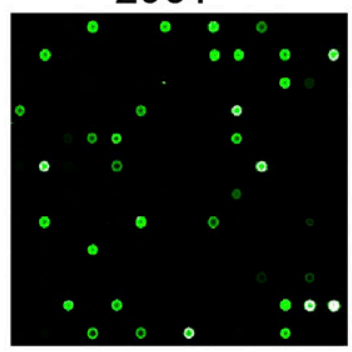

HIV-1

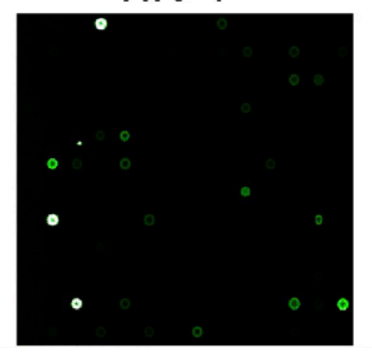

B
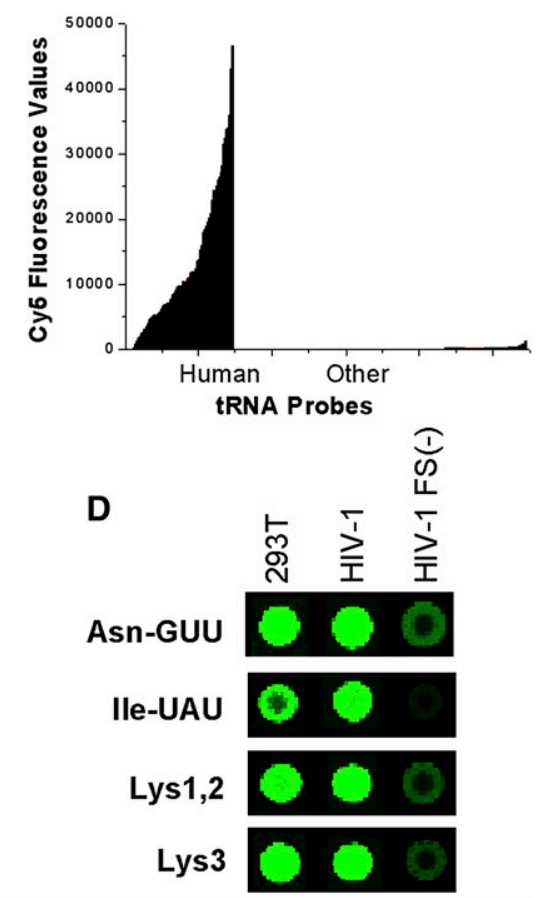

FIGURE 1. Detection of tRNAs by microarray analysis. (A) Array scheme. Total cellular or viral RNA were deacylated, and directly labeled with a Cy3 or Cy5 containing oligonucleotide using T4 DNA ligase. The labeling samples with the opposite fluorophores were combined and hybridized together on the array. (B) Array specificity. Fluorescence values for the total RNA of HEK293T using human tRNA probes and other probes (Caulobacter tRNA, human rRNA). (C) Array images of one block in the human tRNA microarray hybridized with 293T or HIV-1. Only Cy3 spots are shown for better visualization. The entire array contains 48 blocks, and each probe is repeated 21 times on the array. The particular block shown contains two probes for human $\mathrm{tRNA}^{\mathrm{Lys} 3}$, one for tRNA ${ }^{\text {Asn }}$, and one for a yeast tRNA ${ }^{\text {Phe }}$ standard (SCPhe). Both images have the same contrast for the SCPhe standard. In the array key grid, gray squares indicate probe locations for human tRNAs and open squares indicate probe locations for nonhuman tRNA or rRNA. (D) Selected spots from Cy3-labeled 293T total RNA, wild-type HIV-1, or GagVLP, indicating that significantly lower amounts of tRNA are present in GagVLPs. 

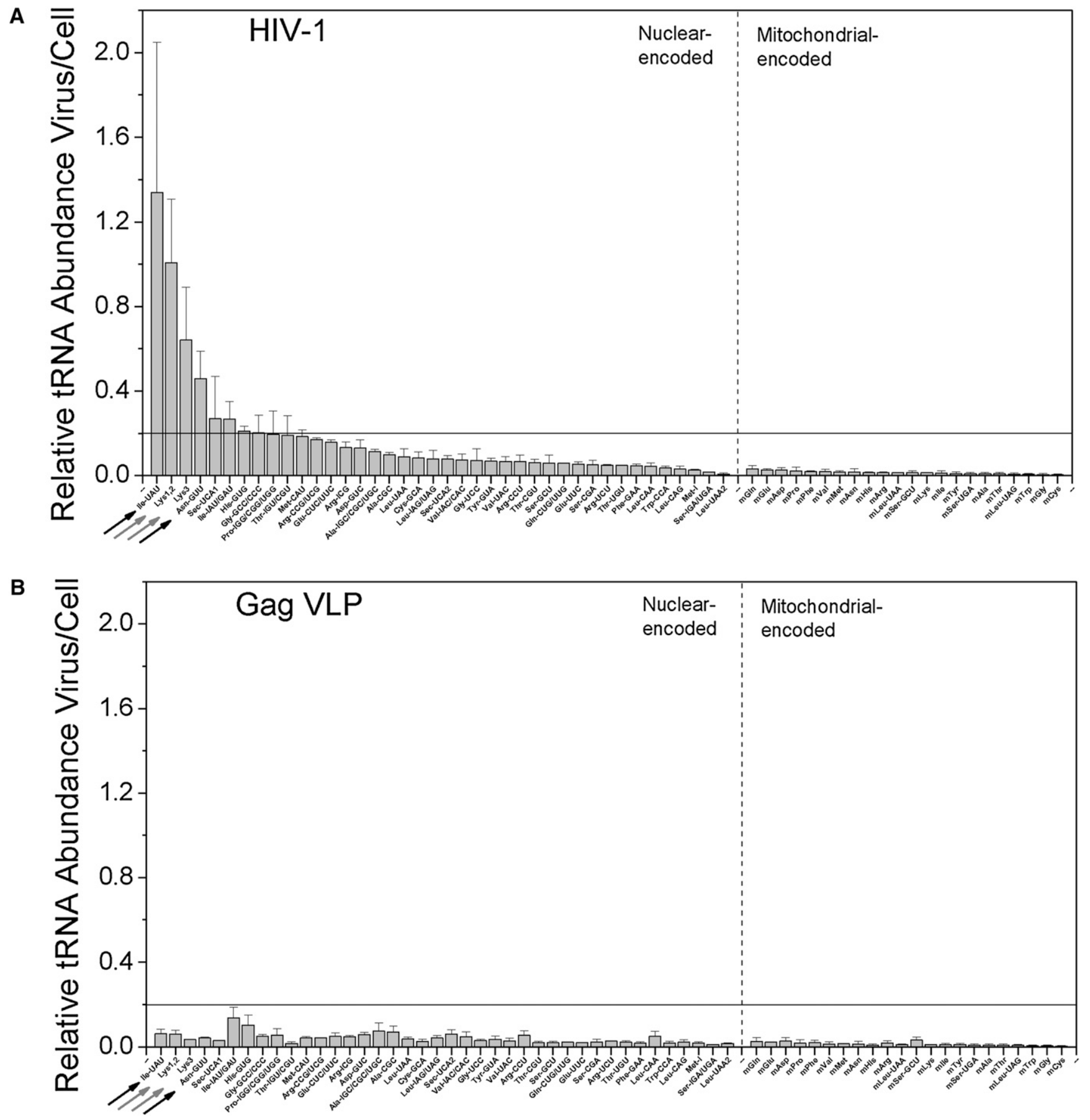

FIGURE 2. Selective packaging of tRNAs into HIV-1. Each bar represents the HIV-1:cell ratio for a specific tRNA. DNA probes on the microarray are complementary to either nuclear-encoded or mitochondrial-encoded tRNAs. (A) Ratios using tRNA in wild-type HIV-1. (B) Ratios using tRNA present in Gag VLPs lacking GagPol. RNA $^{\text {Lys1,2 }}$ and tRNA ${ }^{\text {Lys } 3}$ probes are indicated by gray arrows, and tRNA ${ }^{\text {Asn }}$ and tRNA $^{\text {Ile(UAU) }}$ probes are indicated by black arrows.

are selectively packaged into virions. For HIV-1 (Fig. 2A), a majority of the nuclear-encoded tRNAs show ratios between 0.01 and 0.2 , while four tRNAs show significantly higher ratios than 0.2. For Gag VLPs, all nuclear-encoded tRNAs show ratios below 0.2 (Fig. 2B). These results also indicate that the amount of tRNAs packaged into GagVLPs is significantly reduced as compared to HIV-1. All mitochondrial-encoded tRNAs in both HIV-1 and GagVLPs show values below 0.05 , indicating they are not incorporated into virions. Assuming tRNAs present in GagVLP samples represent nonselective incorporation, we use the value of 0.2 as a cutoff for selective packaging. By this criterion, four tRNAs 
are selectively incorporated into $\mathrm{HIV}-1$ virions by a factor of twofold or more: tRNA ${ }^{\text {Ile(UAU) }}(1.4)$, tRNA ${ }^{\text {Lys } 1,2(\mathrm{CUU})}(1.0)$, tRNA $^{\text {Lys3(UUU) }}(0.65)$, and tRNA ${ }^{\text {Asn(GTT) }}(0.4)$.

We next calculated from our microarray data the concentration of each tRNA relative to the total tRNA population, as determined by the percent of the total fluorescence signal obtained from each labeled tRNA (Fig. 3A,B). Although this type of analysis is uncommon for two-color microarray studies, we believe this analysis can be justified for this tRNA study: (1) our fluorescence labeling scheme relies only on the $3^{\prime} \mathrm{NCCA}$, which is single-stranded and universal in all tRNAs; (2) our labeling scheme does not require reverse transcription, and is therefore less sensitive to tRNA structure or modifications; (3) the array probes have a nearly uniform melting temperature; and (4) there is a very good agreement between the percent tRNAs determined by the array and 2D gel electrophoresis methods, as will be shown in Figure 3, C and D.

As expected, the tRNA ${ }^{\text {Lys }}$ isoacceptors represent the majority of the total tRNA population in HIV-1 (Fig. $3 \mathrm{~A}, \mathrm{~B}) . \mathrm{tRNA}^{\mathrm{Lys}}$ isoacceptors together represent $35 \%$ of total tRNA in HIV-1 versus only $4.5 \%$ in $293 \mathrm{~T}$ cells, indicating an eightfold selective packaging. tRNA ${ }^{\text {Asn(GTT) }}$ represents $11 \%$ of total tRNA in HIV-1 versus $3.4 \%$ in $293 \mathrm{~T}$ cells, indicating a threefold selective packaging. Finally, tRNA ${ }^{\mathrm{Ile}(\mathrm{UAU})}$ represents $4 \%$ of total tRNA in HIV-1 versus $0.6 \%$ in $293 \mathrm{~T}$ cells, indicating a sevenfold selective packaging. Though tRNA $^{\mathrm{Ile}(\mathrm{UAU})}$ has a high selection relative to cellular RNA, it is one of the less abundant tRNAs present in HIV-1. This reflects the fact that tRNA ${ }^{\mathrm{Ile}(\mathrm{UAU})}$ is one of the rare tRNAs in $293 \mathrm{~T}$ cells. The human genomic codon usage for isoleucine has frequencies of 47\% (AUC), 36\% (AUU), and $17 \%$ (AUA). In contrast, the HIV-1 genomic codon usage for isoleucine has frequencies of 18\% (AUC), 29\% (AUU), and 54\% (AUA) (Nakamura et al. 2000). The tRNA ${ }^{\text {Ile(UAU) }}$ selectively packaged in HIV only reads the AUA codon, which is the rare Ile codon in human, but the most common Ile codon in HIV-1. As for GagVLPs, the total amount of tRNA packaged is reduced by $80 \%$ compared to the wildtype HIV-1, assuming that the total RNA contains similar amounts of viral RNA in HIV and GagVLP.

\section{Analysis of major viral tRNA species using 2D PAGE}

Total viral or Gag VLP RNA was 3'-end-labeled with ${ }^{32} \mathrm{pCp}$, and labeled tRNAs were resolved by 2D PAGE, which only lets in low molecular weight RNAs into the gel. For wild-type HIV-1 (Fig. 3D), the identity of the major
A

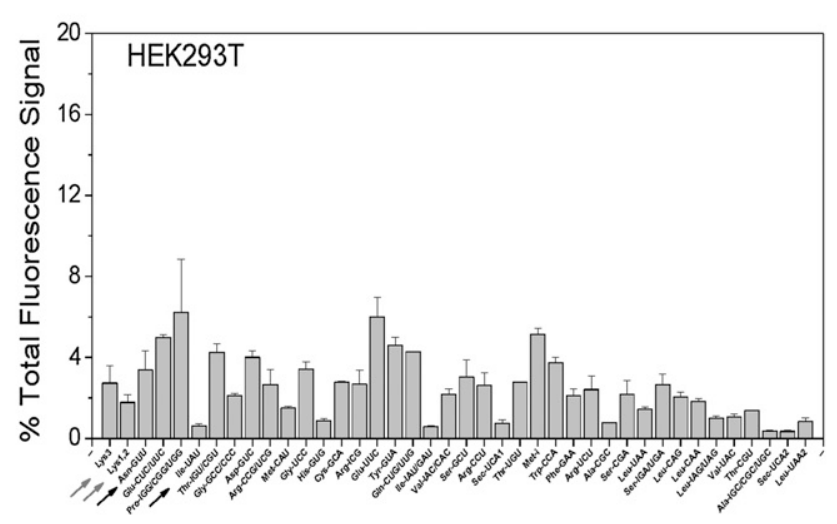

B

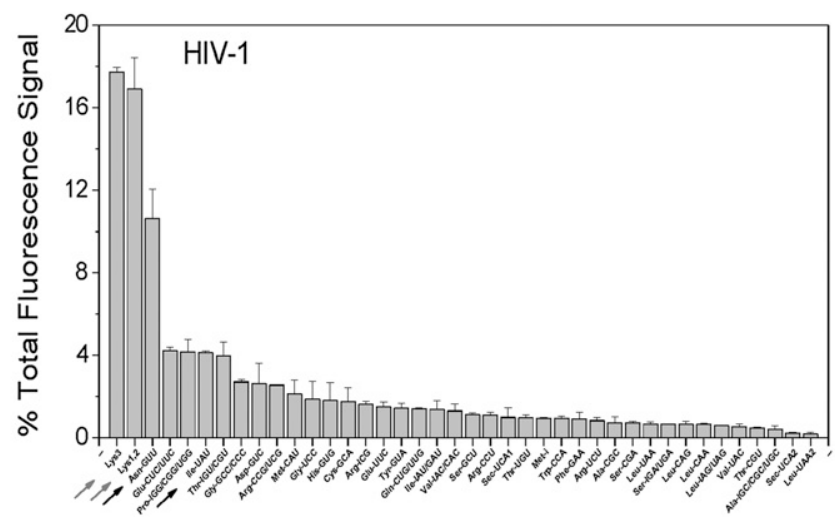

C

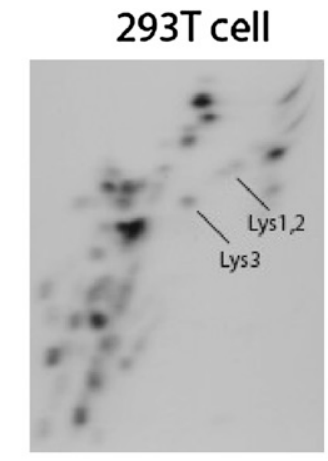

D

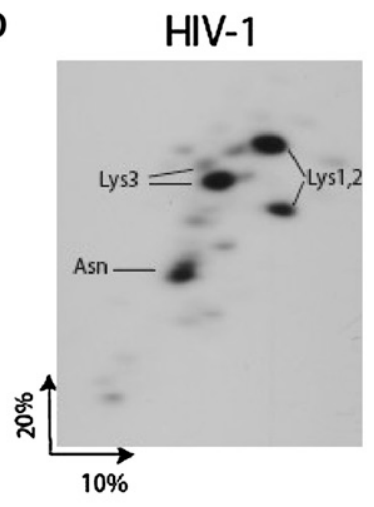

Gag VLP

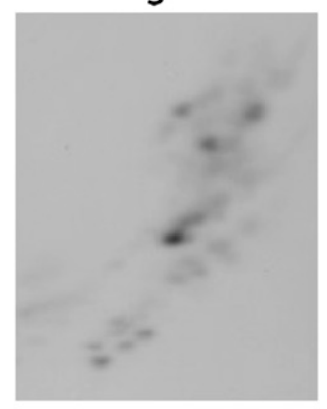

FIGURE 3. Abundance of tRNAs in HIV-1. tRNA abundance is expressed as percent of total tRNA fluorescence signal in HEK293 tRNA ( $A$ ) and HIV-1 tRNA (B). Only nuclear-encoded tRNAs are shown. $(C, D)$ Analysis of low molecular weight RNA in HEK293T cells, HIV-1, and Gag VLPs by 2 D PAGE. Total RNA was $3^{\prime}$ labeled with ${ }^{32} \mathrm{pCp}$. For purposes of quantitative comparison, all samples used equal amounts of viral genomic RNA, were electrophoresed in the same chamber, and exposed to either film or to phosphorimaging at the same time. 
tRNA $^{\text {Lys }}$ isoacceptors has been previously reported (Jiang et al. 1993), including a minor tRNA ${ }^{\text {Lys3 }}$ isoacceptor (Gabor et al. 2002). The species marked tRNA ${ }^{\text {Asn }}$ was identified by (1) amplifying the RNA in the spot using RT/ PCR with primers specific for this tRNA, and (2) allowing radioactivity in a Northern blot of the gel to decay, and then hybridizing the blot with a labeled DNA probe specific for tRNA ${ }^{\text {Asn }}$ (data not shown). Because the tRNA ${ }^{\text {Ile }}$ spot does not stand out among the remaining spots, consistent with the microarray abundance data, we did not attempt the validation of tRNA ${ }^{\text {Ile }}$ using these methods.

We also analyzed the tRNA pattern in GagVLPs (Fig. 3D). To compare the results quantitatively, the gels for the wild-type and GagVLP samples were loaded with equal amounts of viral genomic RNA (representing equal numbers of viral particles), electrophoretically resolved at the same time in the same chamber, and exposed afterward to film for the same length of time (Table 1). Measurements of total radioactive tRNA species in the gel indicate that in GagVLPs, the amount of tRNA incorporated is reduced by $84 \%$ compared to HIV-1, a result very similar to that obtained using microarray analysis (80\%). In HIV-1, the percentage of total radioactivity present in the tRNA ${ }^{\text {Lys }}$ (37.4\%) isoacceptors and tRNA ${ }^{\text {Asn }}(9.5 \%)$ is very similar to that determined by microarray analysis $(34.6 \%$ and $10.6 \%$, respectively) (Table 1). Maintenance of the pattern of selection of tRNA ${ }^{\text {Lys }}$ isoacceptors does not appear to be due to a preference for labeling tRNA ${ }^{\mathrm{Lys}}$ isoacceptors with ${ }^{32} \mathrm{pCp}$, as indicated by the 2D PAGE pattern for $293 \mathrm{~T}$ cellular low molecular weight RNA (Fig. 3C).

These data support a previous observation that in HIV-1 containing a deletion in reverse transcriptase and integrase sequences, there was an eightfold decrease in tRNA ${ }^{\text {Lys3 }}$ in the virion (Mak et al. 1994). The severe reduction or elimination of selective packaging of tRNA ${ }^{\text {Lys }}$ isoacceptors and tRNA $^{\text {Asn }}$ in Gag VLPs suggests that other tRNAs incorporated into virions may also depend upon interaction with GagPol for their incorporation.

\section{Concluding remarks}

At this time, we do not know why non-lysyl tRNAs are selectively packaged into HIV-1. We cannot rule out the possibility that non-lysyl tRNAs are packaged as by-

TABLE 1. Quantitative comparison of microarray and 2D PAGE results

\begin{tabular}{lcccc}
\hline \%tRNA & $\begin{array}{c}\text { HIV-1 } \\
\text { (microarray) }\end{array}$ & $\begin{array}{c}\text { HIV-1 } \\
\text { (2D PAGE) }\end{array}$ & $\begin{array}{c}\text { GagVLP } \\
\text { (microarray) }\end{array}$ & $\begin{array}{c}\text { GagVLP } \\
\text { (2D PAGE) }\end{array}$ \\
\hline Lys3 & $17.7 \pm 0.3$ & $13.5 \pm 1.5$ & $3.4 \pm 0.2$ & $4.0 \pm 0.8$ \\
Lys1,2 & $16.9 \pm 1.5$ & $23.9 \pm 3.3$ & $4.4 \pm 0.5$ & $6.5 \pm 0.2$ \\
Asn & $10.6 \pm 1.4$ & $9.5 \pm 1.1$ & $4.6 \pm 0.5$ & $6.0 \pm 0.9$
\end{tabular}

GagVLP [all tRNA]/HIV1 [all tRNA] $=20 \pm 2 \%$ (microarray); $16 \pm 3 \%$ (2D PAGE). products of tRNA ${ }^{\text {Lys }}$ packaging and play no relevant role in retroviral biology. Like tRNA ${ }^{\text {Lys } 1,2}$, non-lysyl tRNAs may also facilitate the import of the pre-integration complex into the nucleus (Zaitseva et al. 2006). Since the lysyl-tRNA (LysRS) and asparagyl-tRNA (AsnRS) synthetases belong to the same structural group (class IIB) (Delarue and Moras 1993), it is possible that tRNA ${ }^{\mathrm{Asn}}$ incorporation is due to a secondary interaction with LysRS. However, the human tRNA $^{\text {Asn }}$ and tRNA ${ }^{\text {Lys }}$ sequences differ by over 30 nucleotides (nt), suggesting that they are indeed different species and that any function played by tRNA ${ }^{\text {Asn }}$ and $t R^{2} A^{\text {Lys }}$ is not interchangeable. Interestingly, tRNA ${ }^{\mathrm{Ile}(\mathrm{UAU})}$ is rare in human cells, but reads the most common Ile codon in the HIV-1 genome. Selective incorporation of tRNA ${ }^{\text {Ile(UAU) }}$ into HIV-1 may facilitate translation of key HIV-1 proteins.

Regardless, our result has a practical bottom line: tRNA profiling by microarray is a very useful and convenient tool that can be easily applied to the studies of other viruses or other biological processes for which unknown tRNA species need to be identified. Aside from retro-viruses, early reports show that $(-)$ sense single-stranded RNA viruses also contain multiple, unidentified tRNA species in the virion (Kolakofsky 1972; Isaac and Keene 1981). Our tRNA microarray method can be readily applied to determine whether selective packaging also occurs in other viruses.

\section{MATERIALS AND METHODS}

\section{Microarray analysis}

The tRNA microarray experiment, described in detail by Dittmar et al. (2006) and Pavon-Eternod et al. (2009), consists of four steps starting from total RNA: (1) deacylation to remove remaining amino acids attached to the tRNA; (2) selective Cy3/Cy5 labeling of tRNA; (3) hybridization on commercially printed arrays; and (4) data analysis.

\section{Deacylation}

Total viral $(0.25 \mu \mathrm{g} / \mu \mathrm{L})$ or cellular RNA was spiked with three tRNA standards (Escherichia coli tRNA ${ }^{\text {Lys }}$, E. coli tRNA ${ }^{\text {Tyr }}$, and yeast $\mathrm{tRNA}^{\mathrm{Phe}}$ ) at $0.67 \mathrm{pmol}$ each $/ \mu \mathrm{g}$ total RNA. The mixture was incubated in $100 \mathrm{mM}$ Tris- $\mathrm{HCl}\left(\mathrm{pH} \mathrm{9.0)}\right.$ at $37^{\circ} \mathrm{C}$ for $30 \mathrm{~min}$. The solution was neutralized by the addition of an equal volume of 100 $\mathrm{mM} \mathrm{Na}$-acetate/acetic acid ( $\mathrm{pH} 4.8$ ) plus $100 \mathrm{mM} \mathrm{NaCl}$, followed by ethanol precipitation. Deacylated total RNA was dissolved in water, and its integrity verified by agarose gel electrophoresis.

\section{Cy3/Cy5 labeling}

tRNA in the total RNA mixture was selectively labeled with either Cy3 or Cy5 fluorophore using an enzymatic ligation method previously described (Dittmar et al. 2006). The ligation reaction relies on an 8-bp RNA:DNA hybrid helix containing a Cy3 
or Cy5 fluorophore pre-attached to the loop and an overhang complementary to the universally conserved 3 'CCA nucleotides present in all tRNAs (Fig. 1A). The ligation reaction was carried out overnight $(\sim 16 \mathrm{~h})$ at $16^{\circ} \mathrm{C}$ with $0.13 \mu \mathrm{g} / \mu \mathrm{L}$ total RNA in $1 \mathrm{X}$ T4 DNA ligase buffer, $0.5 \mathrm{U} / \mu \mathrm{L}$ T4 DNA ligase (USB Corporation, 70042X), 15\% DMSO, and $4.5 \mu \mathrm{M}$ labeling oligonucleotide.

\section{Hybridization}

Hybridization was performed at $60^{\circ} \mathrm{C}$ overnight $(\sim 16 \mathrm{~h})$ with $1-2 \mu \mathrm{g}$ each of Cy3- or Cy5-labeled total RNA as previously described (Dittmar et al. 2004). Multiple arrays were run using the 293T cell reference sample labeled with either Cy3 or Cy5.

\section{Data analysis}

Arrays were scanned using a GenePix 4000b scanner (Axon Instruments) to obtain fluorescence intensities and the Cy5/Cy3 ratio per pixel at each probe spot. For both $\mathrm{Cy} 3$ and $\mathrm{Cy} 5$ wavelengths, PMT gain was set at 600 and power at $100 \%$. These settings were chosen to provide optimal signal without saturation. Array images were generated and analyzed using GenePix 6.0 software. The median $\mathrm{Cy} 5 / \mathrm{Cy} 3$ ratio per pixel at each probe spot was normalized to an average value of the three tRNA standards prior to subsequent analysis.

\section{Plasmids}

BH10 is a simian virus 40-based vector that contains full-length wild-type HIV-1 proviral DNA. BH10.P - is a simian virus 40based vector that contains full-length wild-type HIV-1 proviral DNA with a single point mutation at position 25 of the protease region, converting Asp25 to Arg25. Transfection of BH10.Pproduces noninfectious viral particles containing wild-type genomic RNA and unprocessed precursor proteins Gag and GagPol (Gottlinger et al. 1989).

\section{Cell culture and transfection}

HEK-293T cells were grown in complete Dulbecco's modified Eagle's medium (DMEM) plus 10\% fetal calf serum (FCS), $100 \mathrm{U}$ of penicillin, and $100 \mu \mathrm{g}$ of streptomycin $/ \mathrm{mL}$. For the production of viruses or viral-like particles (VLPs), HEK-293T cells were transfected with BH10 or BH10.FS- using Lipofectamine 2000 (Invitrogen) according to the manufacturer's instructions.

\section{Virus isolation}

Forty-eight hours after transfection of 293T cells with plasmids coding for wild-type or mutant HIV-1, the virus-containing culture supernatants were collected. Viruses were pelleted from culture medium by centrifugation in a Beckman $45 \mathrm{Ti}$ rotor at $35,000 \mathrm{rpm}$ for $1 \mathrm{~h}$. The viral pellets were then purified by centrifugation in a Beckman SW41 rotor at 26,500 rpm for $1 \mathrm{~h}$ through $15 \%$ sucrose onto a $65 \%$ sucrose cushion. The band of purified virus was removed and pelleted in $1 \mathrm{X}$ TNE in a Beckman $45 \mathrm{Ti}$ rotor at 40,000 $\mathrm{rpm}$ for $1 \mathrm{~h}$ (Cen et al. 2001).

\section{RNA purification, 2D PAGE, and RNA analysis}

Total cellular or viral RNA was extracted from cell or viral pellets by the guanidinium isothiocyanate procedure, and dissolved in $5 \mathrm{mM}$
Tris buffer, pH 7.5 (Cen et al. 2001). To determine the packaging pattern of tRNAs in the viruses, 2D PAGE of ${ }^{32} \mathrm{pCp}-3^{\prime}$-end-labeled total viral RNA was performed as described previously (Jiang et al. 1993). Hybridization to dot blots of viral RNA and tRNAs was carried out with ${ }^{32} \mathrm{P}-5^{\prime}$-end-labeled DNA probes complementary to genomic RNA nucleotides 791-807 (5'-CTGACGCTCTCGCAC CC- $\left.3^{\prime}\right)$, and to the $3^{\prime}$ terminal 18 nucleotides of $\mathrm{tRNA}{ }^{\text {Lys3 }}\left(5^{\prime}-\mathrm{TGG}\right.$ CGCCCGAACAGGGAC- $3^{\prime}$ ) and tRNA ${ }^{\text {Asn }}$ (5'-TGGCGTCCCTGG GTGGGC-3'). Phosphorimaging was used to quantitate the relative amount of HIV-1 genomic RNA per sample and the relative amount of tRNAs.

\section{Identification of $t R N A^{\text {Asn }}$ by sequencing}

The ${ }^{32}$ pCp-labeled RNA species in spot 4 was excised from a fresh 2D PAGE gel, eluted overnight, and ethanol precipitated, as previously described (Wei et al. 2005). RT/PCR was performed upon the purified RNA from spot 4 using ThermoScript RT/PCR system with Platinum Taq (Invitrogen Life Technologies). The primer for reverse transcript to synthesize cDNA of tRNA was 5'-TGGCGTCCCTGGGTGGGCTC-3'. PCR was carried out by using a pair of internal primers (forward primer: $5^{\prime}$-GTGGCGCAATGC GTT-3'; reverse primer: 5'-TGGGTGGGCTCGAA-3'). The PCR products were inserted into the pCR4-TOPO vector (Invitrogen Life Technologies) and individual clones were sequenced.

\section{ACKNOWLEDGMENTS}

This work was supported by grants from the National Institutes of Health (USA) (to L.K. and to T.P.) and the Canadian Institutes for Health Research (Canada) (to L.K.). M.P.E. was supported by a Ruth Kirshstein Pre-doctoral Fellowship from the NIH (1F31CA139968). M.P.-E. and M.W. contributed equally to this work. M.P.E. carried out the microarray studies; M.W. carried out the 2D PAGE studies; and L.K. conceived of the study and participated in its design and coordination with T.P.

Received September 14, 2009; accepted October 20, 2009.

\section{REFERENCES}

Cen S, Khorchid A, Javanbakht H, Gabor J, Stello T, Shiba K, MusierForsyth K, Kleiman L. 2001. Incorporation of lysyl-tRNA synthetase into human immunodeficiency virus type 1. J Virol 75: 5043-5048.

Delarue M, Moras D. 1993. The aminoacyl-tRNA synthetase family: Modules at work. Bioessays 15: 675-687.

Dittmar KA, Mobley EM, Radek AJ, Pan T. 2004. Exploring the regulation of tRNA distribution on the genomic scale. J Mol Biol 337: 31-47.

Dittmar KA, Goodenbour JM, Pan T. 2006. Tissue-specific differences in human transfer RNA expression. PLoS Genet 2: e221. doi: 10.1371/journal.pgen.0020221.

Gabor J, Cen S, Javanbakht H, Niu M, Kleiman L. 2002. Effect of altering the $\operatorname{tRNA}_{3}^{\text {Lys }}$ concentration in human immunodeficiency virus type 1 upon its annealing to viral RNA, GagPol incorporation, and viral infectivity. J Virol 76: 9096-9102.

Gottlinger HG, Sodroski JG, Haseltine WA. 1989. Role of capsid precursor processing and myristoylation in morphogenesis and infectivity of human immunodeficiency virus type 1. Proc Natl Acad Sci 86: 5781-5785.

Isaac CL, Keene JD. 1981. Transfer RNAs associated with vesicular stomatitis virus. J Gen Virol 56: 141-151. 
Javanbakht H, Halwani R, Cen S, Saadatmand J, Musier-Forsyth K, Gottlinger H, Kleiman L. 2003. The interaction between HIV-1 Gag and human lysyl-tRNA synthetase during viral assembly. J Biol Chem 278: 27644-27651.

Jiang M, Mak J, Ladha A, Cohen E, Klein M, Rovinski B, Kleiman L. 1993. Identification of tRNAs incorporated into wild-type and mutant human immunodeficiency virus type 1. J Virol 67: 3246-3253.

Khorchid A, Javanbakht H, Wise S, Halwani R, Parniak MA, Wainberg MA, Kleiman L. 2000. Sequences within Pr160gag-pol affecting the selective packaging of primer tRNA ${ }_{3}^{\text {Lys }}$ into HIV-1. J Mol Biol 299: 17-26.

Kolakofsky D. 1972. Transfer ribonucleic acid nucleotidyltransferase and transfer ribonucleic acid in Sendai virions. J Virol 10: 555-559.

Mak J, Jiang M, Wainberg MA, Hammarskjold ML, Rekosh D, Kleiman L. 1994. Role of Pr160gag-pol in mediating the selective incorporation of tRNA ${ }^{\text {Lys }}$ into human immunodeficiency virus type 1 particles. J Virol 68: 2065-2072.

Nakamura Y, Gojobori T, Ikemura T. 2000. Codon usage tabulated from international DNA sequence databases: Status for the year
2000. Nucleic Acids Res 28: 292. url: http://nar.oxfordjournals.org/ cgi/content/full/28/1/292.

Pavon-Eternod M, Gomes S, Geslain R, Dai Q, Rosner MR, Pan T. 2009. tRNA over-expression in breast cancer and functional consequences. Nucleic Acids Res. doi: 10.1093/nar/gkp787.

Raba M, Limburg K, Burghagen M, Katze JR, Simsek M, Heckman JE, Rajbhandary UL, Gross HJ. 1979. Nucleotide sequence of three isoaccepting lysine tRNAs from rabbit liver and SV40-transformed mouse fibroblasts. Eur J Biochem 97: 305-318.

Wei M, Cen S, Niu M, Guo F, Kleiman L. 2005. Defective replication in human immunodeficiency virus type 1 when nonprimers are used for reverse transcription. J Virol 79: 9081-9087.

Zaitseva L, Myers R, Fassati A. 2006. tRNAs promote nuclear import of HIV-1 intracellular reverse transcription complexes. PLoS Biol 4: e332. doi: 10.1371/journal.pbio.0040332.

Zhou Y, Goodenbour JM, Godley LA, Wickrema A, Pan T. 2009. High levels of tRNA abundance and alteration of tRNA charging by bortezomib in multiple myeloma. Biochem Biophys Res Commun 385: $160-164$. 

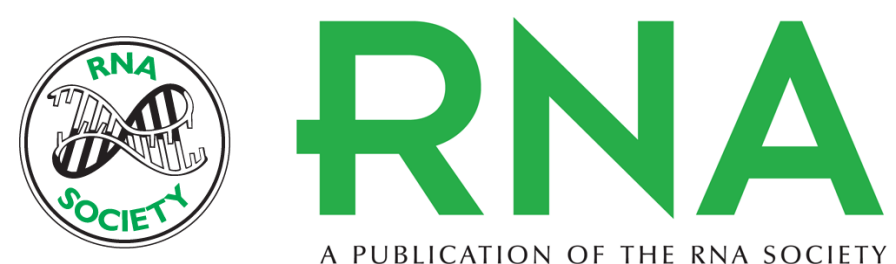

A PUBLICATION OF THE RNA SOCIETY

\section{Profiling non-lysyl tRNAs in HIV-1}

Mariana Pavon-Eternod, Min Wei, Tao Pan, et al.

RNA 2010 16: 267-273 originally published online December 9, 2009

Access the most recent version at doi:10.1261/rna.1928110

\section{References This article cites 18 articles, 8 of which can be accessed free at:} http://rnajournal.cshlp.org/content/16/2/267.full.html\#ref-list-1

\section{License}

Email Alerting Receive free email alerts when new articles cite this article - sign up in the box at the Service top right corner of the article or click here.

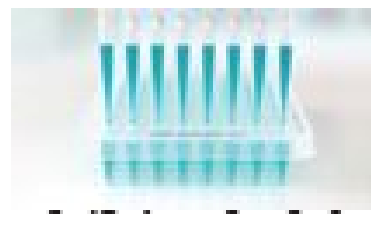

\section{Providing Precise Solutions for} your research.

To subscribe to RNA go to:

http://rnajournal.cshlp.org/subscriptions 